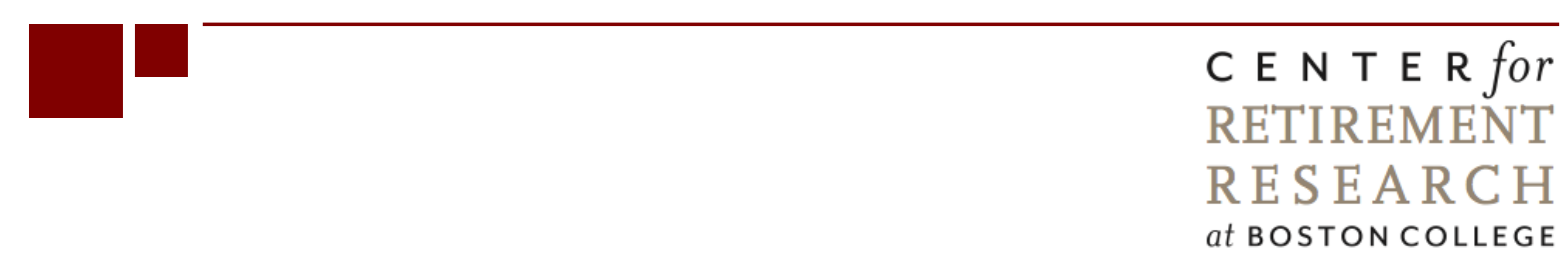

\title{
INTEREST RATES AND ECONOMIC GROWTH: ARE THEY RELATED?
}

\author{
Barry P. Bosworth \\ CRR WP 2014-8 \\ Submitted: January 2014 \\ Released: May 2014
Center for Retirement Research at Boston College
Hovey House
140 Commonwealth Ave
Chestnut Hill, MA 02467 \\ Tel: 617-552-1762 Fax: 617-552-0191 \\ http://crr.bc.edu
}

Barry P. Bosworth is a senior fellow in economic studies at The Brookings Institution. The research reported herein was pursuant to a grant from the U.S. Social Security Administration (SSA), funded as part of the Retirement Research Consortium (RRC). The findings and conclusions expressed are solely those of the author and do not represent the views of SSA, any agency of the federal government, the RRC, The Brookings Institution, or Boston College. The author is indebted to Mattan Alalouf from The Brookings Institution for computational assistance.

(C) 2014, Barry P. Bosworth. All rights reserved. Short sections of text, not to exceed two paragraphs, may be quoted without explicit permission provided that full credit, including (C) notice, is given to the source. 


\begin{abstract}
About the Center for Retirement Research
The Center for Retirement Research at Boston College, part of a consortium that includes parallel centers at the University of Michigan and the National Bureau of Economic Research, was established in 1998 through a grant from the Social Security Administration. The Center's mission is to produce first-class research and forge a strong link between the academic community and decision-makers in the public and private sectors around an issue of critical importance to the nation's future. To achieve this mission, the Center sponsors a wide variety of research projects, transmits new findings to a broad audience, trains new scholars, and broadens access to valuable data sources.
\end{abstract}

Center for Retirement Research at Boston College

Hovey House

140 Commonwealth Avenue

Chestnut Hill, MA 02467

phone: 617-552-1762 fax: 617-552-0191

e-mail: crr@bc.edu

crr.bc.edu

Affiliated Institutions:

The Brookings Institution

Massachusetts Institute of Technology

Syracuse University

Urban Institute 


\begin{abstract}
Each year the Board of Trustees of the Old-Age, Survivors and Disability Insurance (OASDI) Trust Funds projects the future financial status of the programs extending as far as 75years into the future. These projections incorporate anticipated trends in both demographic and economic determinants of future costs. Particularly with regard to the economic determinants, the Trustees rely on past trends to project the future, and the projections of individual elements are largely independent of one another. This paper explores the long-term determinants of interest rates, and, in particular, the relationship between variations in interest rates and the rate of economic growth. Is there a positive correlation, as suggested by standard growth theory, or is the role of economic growth overshadowed by a larger array of domestic and foreign influences.

Data from a number of large economies are used to demonstrate the influence of foreign interest rates in an increasingly globalized world capital market. A method is developed to adjust both long and short-term interest rates for expected inflation. The paper suggests that capital markets are highly integrated at the global level and that it makes little sense to model, analyze, or forecast interest rates within a closed-economy framework. Furthermore, there is only a weak relationship between real interest rates and economic growth. Given the complexity of global economic developments, it is unlikely that the OASDI projections can be improved by more formal efforts to model future interest rate changes.
\end{abstract}




\section{Introduction}

Each year the Board of Trustees of the Old-Age, Survivors and Disability Insurance Trust Funds projects the financial status of the programs extending as far as 75 -years into the future. ${ }^{1}$ Similar projections covering a broader number of budget programs are also provided by the Congressional Budget Office (CB0). These projections incorporate anticipated trends in both demographic and economic determinants of future costs. Particularly with regard to the economic trends, both agencies rely on the evaluation of past trends to form their judgments. Furthermore, the projections of individual elements are largely independent of one another. For example, the projected growth of GDP is the product of the change in the labor force times the increment to labor productivity, but the two component growth rates are independently derived.

In addition to an intermediate or most-likely projection, the OASDI reports include lowcost (from the perspective of program costs) and high-cost alternative scenarios. In those alternatives, the individual elements are largely grouped on the basis of their effects (positive or negative) on the cost projections, without regard for any underlying correlation with one another. For example, a higher rate of productivity growth, increased fertility and a higher real interest rate are combined in the low-cost option not because of any implied causal relationship, but because they all contribute to a more favorable outcome for the trust funds. ${ }^{2}$

In the projections of a pay-as-you-go pension system, the interest rate has little influence, but in the past two decades it took on a more central role as the OASDI system temporarily transitioned to a partially-funded program with a significant inflow of interest income.

Furthermore, the actuaries were frequently called on to evaluate alternatives that included funded individual accounts. The interest rate is also of some significance in computing the present value of the long-run actuarial deficit which is smaller in the near term than in the distant future. Interest rate projections have also become more important in the long-run evaluations of the budget published by CBO because of the rising magnitude of the public debt relative to GDP. For example, in its latest projections the CBO begins with a real 10 -year bond rate of $1 / 2$ percent in 2013 and raises it to its historical average of 3 percent by 2024- assuming that the current

\footnotetext{
${ }^{1}$ The 75-year horizon can be viewed as roughly equivalent to the remaining life of a worker entering the system today, but the reports also place considerable emphasis on shorter horizons of 10, 25,and 50 years.

${ }^{2}$ One exception is the rate of price inflation, where a lower projected rate is associated with the low cost option even though it leads to a worsening of the long-run actuarial balance. Inflation, if reflected in nominal wages, affects revenues immediately, but benefits with a lag, leading to a positive correlation between inflation and the actuarial balance.
} 
episode of extremely low interest rates is transitory. ${ }^{3}$ The result is a growth in the interest share of the budget from one to five percent by 2038.

The intent of this paper is to explore the long-term determinants of interest rates in greater detail, and, in particular, the relationship between variations in interest rates and economic growth. The extraordinary rise of real interest rates in the mid-1980s stimulated considerable research on their determinants (Blanchard and Summers, 1984, and Barro and Salai-Martin, 1990). But by the early 2000s, the focus had shifted to efforts to explain the causes of what was widely viewed as an unusually low level of global rates (Ahearn and others, 2006); and currently the United States and most of Europe have joined Japan in experiencing negative shortterm real interest rates and long-term rates near zero.

A central issue arises in making long-run projections of the future: should the projections of interest rates be made solely within the context of their own history, or should they be constructed within a larger model that takes account of their correlation with other variables? As we shall see, the extent to which interest rate are determined within a global market versus a domestic context is a central issue for that discussion. The paper begins with a brief outline of an analytical framework that highlights some of the major issues. It is followed by a summary of the existing literature. The third section uses panel data for the G-7 and 22 OECD countries to explore the empirical issues in greater detail.

\section{Analytical Framework}

The simple analytics of the relationship between interest rates and economic growth can be illustrated with a constant-returns-to-scale production function in which capital (K), labor (L), and labor-augmenting technical change (E) are combined to produce aggregate output (Y):

$$
Y=K^{\alpha}(L E)^{1-\alpha} .
$$

Assume further that growth of the labor force (n) and labor-augmenting technical change (g) are both determined exogenously, capital depreciates at $\delta$, and the share of gross income that is saved is given by s. In addition, in a closed-economy all of the saving is devoted to increasing the capital stock. The marginal product of capital is given by:

$$
r=\alpha \frac{Y}{K}
$$

\footnotetext{
${ }^{3}$ The trustees' 2013 report incorporates a nearly identical set of assumptions for its projection of the interest of government bonds in the trust fund.
} 
This is the essence of the neoclassical model developed by Solow (1956) and Swan (1956). In steady-state, both output and the capital stock will grow at the rate of $n+g$, and the rate of return is given by:

$$
\text { (3) } \quad r=\alpha\left(\frac{n+g+\delta}{s}\right) \text {. }
$$

In the long run, the rate of return will vary positively with the growth of the economy and the rate of capital depreciation, and negatively with the rate of saving.

However, the above formulation is influenced both by the specification of a fixed saving rate and the assumption of a closed economy. Cutler and others (1990) in their exploration of the effects of declining population growth extended the Solow model to incorporate an internal determination of the aggregate saving rate. In particular, they adopted a version of the Ramsey model of optimal saving over an infinite future time period. In that formulation, the rate of saving responds to demographic changes: lower rates of population growth require less saving. However, by specifying a closed-economy in their main theoretical model, they explicitly assumed that future rates of saving and investment must move in tandem. As a result, saving and investment will adjust to yield a rate of return that is invariant to variations in the rate of population growth.

Second, if we drop the assumption of a closed economy and allow saving and investment to be determined within open economies in which savers are free to invest in other countries, there is no reason whatsoever to believe that national saving and domestic investment will be equal in every future year. Differences between saving and investment can be absorbed by changes in the current account balance. By investing abroad, savers in maturing economies can avoid the implication of a falling domestic rate of return. ${ }^{4}$ The interest rate will be thereby be determined by the interaction of the supply and demand of investable funds at the global level.

In their empirical work, most researchers have adopted an intermediate position in which a specific country's interest rate is influenced by both domestic and global factors: countries are neither completely open nor completely closed. The determination of interest rates and other asset returns are evaluated within the framework of models of investment and saving behavior at both the national and global levels; the rate of economic growth is only one of several

\footnotetext{
${ }^{4}$ According to the International Monetary Fund, only a few countries have accumulated significant international net investment positions: China (S1.7 trillion), Germany (\$1.4 trillion, Japan (\$3.4 trillion) and the United States (-\$3.9 trillion).
} 
determinants of that balance. However, the simple conceptual framework does highlight two critical empirical issues for modeling the relationship between economic growth and interest rates. First, is there a strong linkage between the rates of return on physical and financial capital; and second, what is the relative importance of domestic versus global factors in the determination of national interest rates? ${ }^{5}$

\section{A Review of the Empirical Literature}

Much of the modern empirical research on the determinants of real interest rates dates from the surge of rates in the early 1980s. While the initial increases were widely attributed to the adoption of a tight monetary policy in the United States, the effects of that policy were expected to be transitory. The continuation of high real rates in the presence of declining inflation led to explorations of a wider set of potential explanations. Blanchard and Summers (1984) highlighted the global nature of the interest rate increases, focusing on six large OECD economies. Most of their analysis focused on short-term rates, because of the lack of measures of expected inflation over extended time horizons required to construct a measure of the long-term real bond rate. They created an estimate of the expected inflation rate from the forecast of a simple autoregressive model of actual inflation, and analyzed changes in four basic determinants: the anticipated profitability of investment, saving, monetary policy, and portfolio preferences. They concluded that enhanced profitability and shifts in the mix of fiscal-monetary policy were the primary factors behind the rise in real rates.

Barro and Sala-i-Martin (1990) went further and postulated a global market for capital in which the interest rate is determined via the interaction between global investment demands and desired saving. They expanded the analysis to ten OECD countries and computed a world real interest rate as a weighted average of the national rates, using purchasing-power-parity measures of GDP to compute the individual share weights. As with the analysis of Blanchard and Summers, they focused on the short-term (three-month) interest rate, and emphasized shifts in the saving-investment balance as their basic analytical framework. They used the stock market as a proxy for variations in investment demand and changes in oil prices to account for changes

\footnotetext{
${ }^{5}$ Baker, DeLong and Krugman (2005) used the standard Solow growth model to assert a positive relationship between economic growth and real rates of returns to capital, and they argued that slower future growth will lead to lower returns. However, they did not attempt to investigate the empirical validity of the model.
} 
in incomes and desired saving. In their model, the real interest rate is a function of changes in the physical economy and there is little role for monetary or fiscal policy.

Orr and others (1995) used a panel data set covering 17 countries to investigate the determinants of long-term ( $\sim 10$ years) real interest rates. They computed the real rate by simply subtracting a smoothed (H-P Filter) measure of the annual inflation rate from the nominal 10year bond rate. However, that measure implies a mismatch of the time horizon for the nominal interest rate and expected inflation that may have distorted their estimates of the implied real rates. They reported a significant positive correlation with the rate of return on physical capital, and past rates of inflation, and a negative association with the government budget balance and the current account. They also found significant spillover effect from interest rates in other countries. Another study using panel data, Ford and Laxton (1999), showed that an aggregate of OECD debt to GDP was a significant determinant of short-term real interest rates in member countries and that the aggregate measure often eliminated the influence of own-country debt. The result offered further support for the view of an integrated world capital market.

Most estimates of the world interest rates peaked around 1990 and began a long period of steady decline. That led to gradual shift in the focus of the research toward efforts to account for what emerged as an unusually low level of interest rates. Ahrend, Catte, and Price (2006) provide an extensive review of the behavior of nominal and real long-term bond rates in the major OECD countries. Their measure of the real rate is based on surveys of inflation expectations that limit most of their analysis to a period beginning with 1990 or an H-P average of actual inflation for a longer time period. They point to a general decline of long-term rates since the mid-1980s in all of the economies, a relatively flat yield curve, and a compression of risk premiums. They attribute these changes to the greater credibility of monetary policy that has narrowed the range of expected future interest rates, shifts in the pattern of global saving and investment, and increased portfolio preferences for bonds over risky equities.

Desroches and Francis $(2006,2010)$ develop an expanded version of the Barro and Salai-Martin model and emphasize a saving-investment framework to explain variations in a measure of the world real interest rate. They use aggregates of annual data for 35 advanced and emerging economies to represent the world economy and estimate regressions for world investment and saving over the period of 1970-2004. Real interest rates are equal to the nominal 5-year government bond rate minus expected inflation. Inflation expectations are calculated using 5- 
year ahead dynamic forecast from an autoregressive model of the actual inflation rate. They point to changes in labor force growth, stock market returns and financial deregulation as major determinants of investment; and saving is related to the age structure of the population, oil prices, government fiscal balances and short-term fluctuations in income.

Finally, Brzoza-Brzezina and Cuaresma (2008) use a dynamic factor model to investigate the relative importance of domestic and international factors as determinants of short-term real interest rates in 22 OECD countries over the period of 1985-2005. They find that the common world factor accounts for about half of the variance of real rates and that its role was growing up to about the mid-1990s, after which it leveled out and remained relatively constant. Individual country factors are also more important in countries with floating exchange rates.

The common theme of all of these empirical studies is emphasis on the importance of adopting a global perspective in the determination of national measures of interest rates. However, while the spillovers across national capital markets are substantial, most studies find that the convergence to a single global market is still incomplete. All the same, these crossborder spillover effects highlight the extent to which the interest-rate policies of individual countries impose substantial externalities on others.

\section{Real Interest Rate Measures}

For most analytical purposes, the relevant interest rate measure is the real rate, i.e. the difference between the nominal rate of interest, $i$, and inflation expectations, $\pi^{\mathrm{e}}$ :

$$
r=i-\pi^{e} .
$$

Unfortunately, the expected rate of inflation is largely unobservable, but various methods have been devised to calculate plausible estimates. For short horizons such as a year or less, transformations of the actual inflation rate yield reasonable measures; but more severe problems arise when measuring expected inflation over longer horizons. Yet, short-term interest rates are likely to be dominated by temporary adjustments of monetary policy, whereas long-term rates are more closely linked to returns on physical capital and are the rates that influence saving and investment decisions.

For short horizons, several techniques have been used. First, many countries have fairly long-standing experience with collecting information from annual government or private sector forecasts of the overall economy, which typically embody an outlook for inflation. The OECD, 
for example, has prepared economic forecasts of its member countries for more than 40 years. In addition, various statistical methods can be used to extract the expected component of inflation on the assumption that the underlying forecasts are rational predictors of the future. The Hodrick-Prescott (H-P) filter is a smoothing technique that separates the inflation rate into its expected and unexpected component. Researchers have also used various autoregressive models that estimate current inflation as a function of past rates. The predicted rate from those models can be interpreted as a proxy for the expected inflation rate. All three of these methods yield similar estimates of the expected component for short durations, such as one year, but the two statistical techniques are of limited applicability to longer term horizons such as five or ten years. The United States does have a survey of expected inflation over a ten-year horizon that is based on the view of professional forecasters and can be extended back to 1980, but comparable data for other countries begins only in the early 1990s. ${ }^{6}$ Those data are of limited value because of the lack of significant variation in the recent data on inflation expectations. That may reflect in turn the increased commitment of the monetary authorities to price stability.

Another potential measure of inflation expectations is the differential between the rate of interest on nominal Treasury bonds and Treasury Inflation Protected Securities (TIPS) of a matching maturity. The coupon and principle of TIPS are both indexed to the consumer price index, and the differential would seem to be an ideal measure of inflation expectations. However, the interpretation of the data is complicated by two factors. First, for many years the market for TIPS was relatively small and suffered from a lack of liquidity. Second, in addition to the expected rate of inflation, holders of a nominal bond expect to be compensated for the risk associated with an uncertain rate of inflation. Hence the differential embodies both liquidity and inflation-risk premiums as well as the expected rate of inflation (D'Amico and others, 2010). The U.S. TIPS was introduced in the early 2000s, but the U.K. has had an inflation-indexed security since the mid-1980s. Other countries now issue versions of TIPS, but the historical time span is limited.

Several of these alternative measures of long-term inflation (10-year) expectations are compared in figure 1 for the United States and the UK. The U.S. survey of profession forecasters, displayed in the top panel, varied substantially in the 1980s and 1990s, but the long-

\footnotetext{
${ }^{6}$ The U.S. data are published by the Federal Reserve Bank of Philadelphia, the European Central Bank publishes survey-base estimates beginning in 2000, and Consensus Economics reports data back to 1990. The data from Consensus Economics require a substantial fee and were not used.
} 
term expectations have been firmly anchored around an annual rate of two percent since 2000 . For contrast, an H-P filter is fit to the quarterly rate of change in the GDP deflator. The smoothed H-P component declines more rapidly than the survey measure in the 1980s, but it is more responsive in the 2000s when commodity prices boosted the rate of actual inflation. ${ }^{7}$ A third option, the rate of expected inflation implied in the 10-year TIPS is displayed for 2003 and later quarters. It is comparable to the survey estimate, but with more short-run fluctuation that is probably the result of variation in the risk premiums mentioned above.

The UK does not have a long historical survey of inflation expectations but it has had a significant market for inflation-indexed bonds dating back to the mid-1980s and the Bank of England uses that data to provide an estimate of the implied rate of expected inflation. That estimate is shown in the lower panel of figure 1. Like the measure derived from the U.S. TIPS, the implied rate has considerable short-run variability (noise), but it indicates a sustained fall in expected inflation during the 1980s and 1990s, and a flattening of expectation since 2000. Again the H-P filter is more sensitive to short-run variations in the actual rate of inflation.

The low-frequency measures of expected inflation for both the United States and the U.K. suggest a very backward-looking process for forming inflation expectations with long lags in the adaptation to actual inflation. That is illustrated in the top panel by including a constructed measure of expected inflation based on the predicted values from a regression of the U.S. 10years inflation expectation as a function of past rates of actual inflation. Using a polynomial representation of the lag structure, the coefficients on the lag rate of actual inflation are significant as far as ten years in the past, and the lag structure is relatively flat for all the full period. Simplifying that formulation, the best fitting equation is one with a 40-quarter average of prior rates of actual inflation and an additional term on the most recent five quarters. ${ }^{8}$ The equation accounts for 98 percent of the variation in the expected inflation variable with a standard error of 0.3 percent (annual rate). The lag structure embodied in the U.S. estimate of expected inflation is used to generate a calculated value of the long-term inflation rate for the U.K. Those values for the U.K. are reported in the lower panel and it is noteworthy that they are very comparable with the estimates obtained from the U.K. data for inflation-indexed bonds.

\footnotetext{
${ }^{7}$ This is the same series that is graphed against the actual inflation rate in figure $\mathrm{x}$.

${ }^{8}$ The basic regression is: $0.65 * \mathrm{~A}_{40}+.21 * \mathrm{~A}_{5}+.26$.
} 
Based on these results, calculated values of expected inflation, based on the common lag structure from the United States, are used to construct measures of 10-year real interest rates for all of the G-7 countries. In addition, estimates of the short-term real rates are constructed using an H-P filter of the quarterly rates of change in the GDP deflator of each country as a proxy for inflation expectations. The average G-7 interest rates are then constructed using GDP-share weights for 2000 .

The resulting measures of nominal and real rates, averaged across the G-7 countries, are displayed in figure $2 .^{9}$ The top panel highlights the extended reduction in short-term inflation expectations as indicated by the narrowing of the gap between the nominal and real short-term rates in the 1980s and 1990s. The real rate rose very sharply from negative values in the mid-70s to an average near 6 percent in the first half of the 80s, and then declined on a trend basis to about 3 percent by the late 1990s. The real rate then fell very sharply in the recession of 2001 and has been very cyclical since then.

The movements in the long-term bond rate have been less pronounced. The real rate rose substantially in the early 1980s, reaching a peak of about five percent; and it has been trending down over the past quarter century, dropping below two percent just before the financial crisis. Implied long-term inflation expectations have fallen from a peak near 8 percent in the early 1980 s to only $1 \frac{1 / 2}{2}$ percent over the past ten years. ${ }^{10}$

The steady reduction in restrictions on trade over the past half century, and the near elimination of many forms of capital controls among the larger advanced economies give rise to a recurring question. "Is there a world interest rate?" Certainly, the evidence of convergence is strong within the Euro Zone after 2000, but it is more mixed across the full range of G-7 countries. That outcome is expected for nominal rates since in the absence of a fixed exchange rate there is no requirement for a convergence of the rates of inflation. But even for real interest rates, individual countries can differ in the risk that they might introduce capital controls or default and the extent of future exchange rate changes.

The standard deviation of the cross-national interest rates provides a simple empirical criterion for convergence. Measures are reported in figure 3 for short and long-term interest rates of the G-7. There was a strong divergence of nominal rates among the G-7 countries during the

\footnotetext{
${ }^{9}$ Annual data for each country are reported in appendix A.

${ }^{10}$ The G-7 average is particularly low because of an estimate of a negative rate of expected inflation for Japan.
} 
widespread acceleration of inflation in the 1970s, but considerable convergence after 1980. The convergence can be largely traced to the narrowing of rates of expected inflation across countries and is most evident for nominal rates. The top panel shows the standard deviation of nominal and real short-term rates for the period of 1970-2013. There is a strong downward trend of the standard deviation of nominal rates after 1980s, but with occasional spikes. There is also a sharp drop after the financial crisis as short-term rates in all countries approached the zero bound. Evidence of a convergence of real rates is strong for the early 1980s, but there have been only modest changes in recent years.

The measures of the standard deviations of long-term rates in the lower panel show a similar pattern of convergence since 1980. However, significant differences remain, partly because Japan has been an outlier with negative expected rates of inflation since the early 1990s. The differences are also sensitive to economic crises in individual countries. For example, quantitative easing has pushed real long-term interest rates into the negative range for the United States and the UK while the debt crisis in the Euro Zone has raised their long-term rates. In contrast to the measures of convergence in short-term rates, the standard deviation of long-term rates has increased in recent years. Given the potential for increases in specific-country risks, it is hard to determine if the underlying risk-free interest rates have continued to converge.

\section{Determinants of Interest Rates}

The empirical analysis of this section addresses the question of the primary determinants of real interest rates. The central issue is the relative importance of foreign versus domestic factors. The prior discussion of the literature highlighted the continuing debate over this issue. The papers by Barro and Sala-i-Martin (1990), Ford and Laxton (1999), and Desroches and Francis (2010) adopted a view of a single fully-integrated capital market. However, Blanchard and Summers (1984), Ahrend and others (2006), and Brzoza-Brzezina and Cuaresma (2008), while agreeing that global factors are important, emphasized a continuing role for domestic variables.

This analysis focuses on the determinants of the real interest rates in individual G-7 countries and uses the weighted average interest rate of the other G-7 countries to represent the foreign influence. Domestic measures included a three-year average of the rate of growth in GDP, labor force growth, and the rate of change in an index of stock market prices as alternative 
measures of shifts in domestic investment. Pressures on domestic capital markets were incorporated by including the ratio of government debt to GDP and the current account balance-the gap between domestic saving and investment-scaled by the level of GDP. The average of the debt/GDP ratio across the G-7 countries was also constructed in response to the argument of Ford and Laxton that the global measure was preferred over own-country effects. Except for the measure of the public debt, the data are drawn from the annual Economic Outlook files of the OECD. The debt data are from the IMF and incorporate the historical debt estimates shown in Abbas et. al. (2011). The basic panel data set is constructed for annual data over the period of 1971 to 2012 and results in 303 observations for the long-term bond rate and 297 for the short-term interest rate. A second data set was constructed for a larger set of 19 OECD countries but the data series sometimes begin at a later date. Still it increases the sample to 722 observations. The analysis uses a fixed-effects estimation that averages the coefficient values across the countries.

The basic regression results for the long-term bond rate are reported in table 1 . The reported regressions are simplified to exclude those variables without statistical significance. The coefficient on the foreign interest rate is large with strong statistical significance, implying a high degree of capital market integration. Yet, the domestic debt/GDP ratio also has a positive and significant effect, suggesting some separation between the domestic and international markets. In contrast to the 1990 results of Ford and Laxton, in this analysis the domestic representation of the debt/GDP measure was much preferred over the G-7 aggregate. The current account balance, as a measure of the excess of domestic saving over investment, displayed a significant negative correlation in some formulations, but its role was not consistent. Similarly, the correlation with GDP growth, while positive, was of limited statistical significance. There was no consistent correlation of interest rates with the growth in the labor force or the return on corporate equities.

The lack of a strong correlation with the rate of economic growth is a surprise in view of the prominence given to it in the standard Solow-Swan growth model. The most plausible explanation is based on other research rejecting the notion of a fixed or exogenous rate of saving and asserting a positive relationship between income growth and the rate of saving. The result is a model in which both saving and investment vary in a coordinated fashion with changes in the 
rate of income growth, leaving little or no systematic relationship between output growth and the rate of interest.

The exclusion of observations for the years after the 2008 financial crisis also has no significant influence on the regressions (columns 3 and 4). Similarly, the results are largely unaffected by the inclusion of a larger number of OECD countries (columns 5 and 6). As a further test, aimed at reducing the effects of potential reverse correlation with the foreign rate, the regressions were re-estimated using the one-year lag of the foreign rate. The result (not shown) was a small decline in the overall fit of the regressions, but the coefficient on the foreign rates remained large with high statistical significance. Additionally, the regressions were reestimated to end in 2000, thereby excluding the years of exceptionally low real interest rates. The effects were limited to a modest reduction in the coefficient on the foreign interest rate, consistent with the view that capital markets are becoming more integrated over time. As a final check on the correlation with foreign rates, the equations were estimated separately for each G-7 country (not shown). While there are variations in the coefficients, the magnitude of the effect of the foreign rate remains uniformly high and significant. The United States in particular exhibited a strong correlation of the domestic interest rate with the current and lagged values of the foreign rate.

A parallel set of regressions are reported in table 2 for the short-term interest rate. The results are very similar to those for the long-term rate, and continue to show a strong correlation with the foreign rate and domestic debt/GDP. The correlations with the current account and GDP growth are only weakly significant. Again, the exclusion of the post-2008 observations or the use of the lagged foreign rate had little impact on the results.

With respect to the basic question of whether there is a global market for capital, the answer of this analysis is yes. But at the same time, there are some influences such as the magnitude of public debt that appear to operate at the national level. That may be because the public debt is viewed as an indicator of default risk rather than operating to crowd out sources of other borrowing. There is also a more marginal influence from national indicators, such as the current account balance and the rate of growth of GDP. 


\section{Conclusion}

The most important conclusion resulting from this analysis is that it makes little or no sense to model, analyze, or forecast interest rates within a closed-economy framework. Capital markets, at least among the major advanced economies, are highly integrated; and while there is a marginal role for national influences, real interest rates are largely determined in a global market context. Because exchange rates are still free to vary among most major economies, nominal rates will adjust to reflect differences in rates of inflation.

The measurement of expected inflation is a significant problem since only the United States has a long period of surveying forecasters or investors about their expectations. But the implied rate of inflation obtained from a comparison of interest rates for inflation-indexed and nominal bonds offers promise for the future, as more countries introduce TIPS or their equivalents. In the absence of alternatives, this analysis adopted an assumption that the adaptive relationship between actual and expected rates of long-term inflation observed in the United States can be applied in other countries. Short-term inflation expectations were modeled with a Hodrick-Prescott filtering process.

At the national level, variation in the ratio of public debt to GDP had the most significant influence on real interest rates. There was also some evidence that high rates of national saving relative to domestic investment reduced domestic interest rates as excess capital - as measured by the current account balance - flowed abroad. The empirical results imply a very weak but positive impact of variations in domestic aggregate demand.

Finally, the dominant influence of global factors suggests that interest rate projections should not incorporate any strong relationship to other economic trends in the domestic economy, such as those associated with the aging of the population, since they are likely to be overwhelmed by global developments. The importance of foreign interest rates suggests that future research might build on the work of studies that attempt to build a model of the global economy and global interest rates. While the research suggests that a shift to a global market is still incomplete, this is clearly the direction of future change. The difficulty is that the definition of those countries that ought to be included under the umbrella of a global market is constantly changing, as emerging markets move to reduce their controls on capital flows and become more integrated with the international market. Emerging economies also display a very diverse pattern of demographic change. Some countries (China in particular) resemble advanced 
economies on the cusp of a significant aging of their populations, with an expectation of lower rates of saving and investment. Other countries (India) will be dominated by declines in the proportion of young dependents and increased saving incentives.

Recently, the weakness of the global economy has initiated substantial discussion of a more sustained pattern of an excess of global saving over desired investment, implying a prolonged period of low interest rates. This was a major theme before the crisis, with a focus on the high rates of saving in Asia and OPEC (Bernanke, 2005). In the aftermath of the crisis, the issue has involved a larger number of countries and a concern with both high rates of saving and low investment - a broad global paradox of thrift in which desired saving exceeds the investment that businesses are willing to undertake. 


\section{References}

Abbas, SM Ali, Nazim Belhocine, Asmaa El-Ganainy, and Mark Horton (2011), “Historical Patterns and Dynamics of Public Debt - Evidence From a New Database”, IMF Economic Review, 59(4):717-742.

Ahrend, R., P. Catte, and R. Price. 2006. “Factors Behind Long-Term Interest Rates,” Financial Market Trends, OECD, No. 91, (November).

D’Amico, Stefania, Don Kim, and Min Wei. 2010. “Tips from TIPS: the informational content of Treasury Inflation-Protected Security Prices,” Finance and Economics Discussion Series, Divisions of Research \& Statistics and Monetary Affairs, Federal Reserve Board, 2010-19.

Baker, Dean, J. Bradford DeLong, and Paul Krugman. 2005. "Asset Returns and Economic Growth," Brookings Papers on Economic Activity 2005:1: 289-315

Barro, Robert J., and Xavier Sala-i-Martin. 1990. "World Real Interest Rates,” in NBER Macroeconomics Annual, edited by Olivier J. Blanchard, and Stanley Fischer: 15-61. Cambridge: MIT Press.

Bernanke, Ben S. 2005. The Global Savings Glut and the US Current Account Deficit. Speech to the Virginia Association of Economics. Richmond, VA.

Blanchard, Olivier, and Lawrence Summers. 1984. "Perspectives on High World Real Interest Rates”, Brookings Papers on Economic Activity, 1984:2: 273-334.

Brzoza-Brzezina, Michael, and Jesus Crespo Cuaresma. 2008. "Mr. Wicksell and the Global Economy: What Drives Real Interest Rates?” Working Paper, Oesterreichische Nationalbank.

Cutler, David, James Poterba, Louise Sheiner, and Lawrence Summers. 1990. "An Aging Society: Opportunity or Challenge?" Brookings Papers on Economic Activity, 1990:1: 156.

Desroches, Bridgitte, and Michael Francis. 2007. “Global Savings, Investment, and World Real Interest Rates,” Bank of Canada Review, Winter 2006-07: 3-17. . 2010. "World Real Interest Rates: A Global Saving and Investment Perspective,” Applied Economics, Vol. 42 (22): 2801-16.

Ford, Robert, and Douglas Laxton. 1990. "World Public Debt and Real Interest Rates,” Oxford Review of Economic Policy, vol. 15 (2): 77-94

Orr, Adrian, Malcolm Edey, and Michael Kennedy. 1995. “The Determinants of Real LongTerm Interest Rates: The Evidence from Pooled-Time-Series,” OECD Economic Studies, No. 25: 75-107.

Solow, Robert. 1956. “A Contribution to the Theory of Economic Growth,” The Quarterly Journal of Economics, Vol. 70 (1): 65-94

Swan, Trevor. 1956. “Economic Growth and Capital Accumulation.” Economic Record 32: 344361. 
Figure 1. Alternative Measures of Expected Inflation, 10 Year.

United States

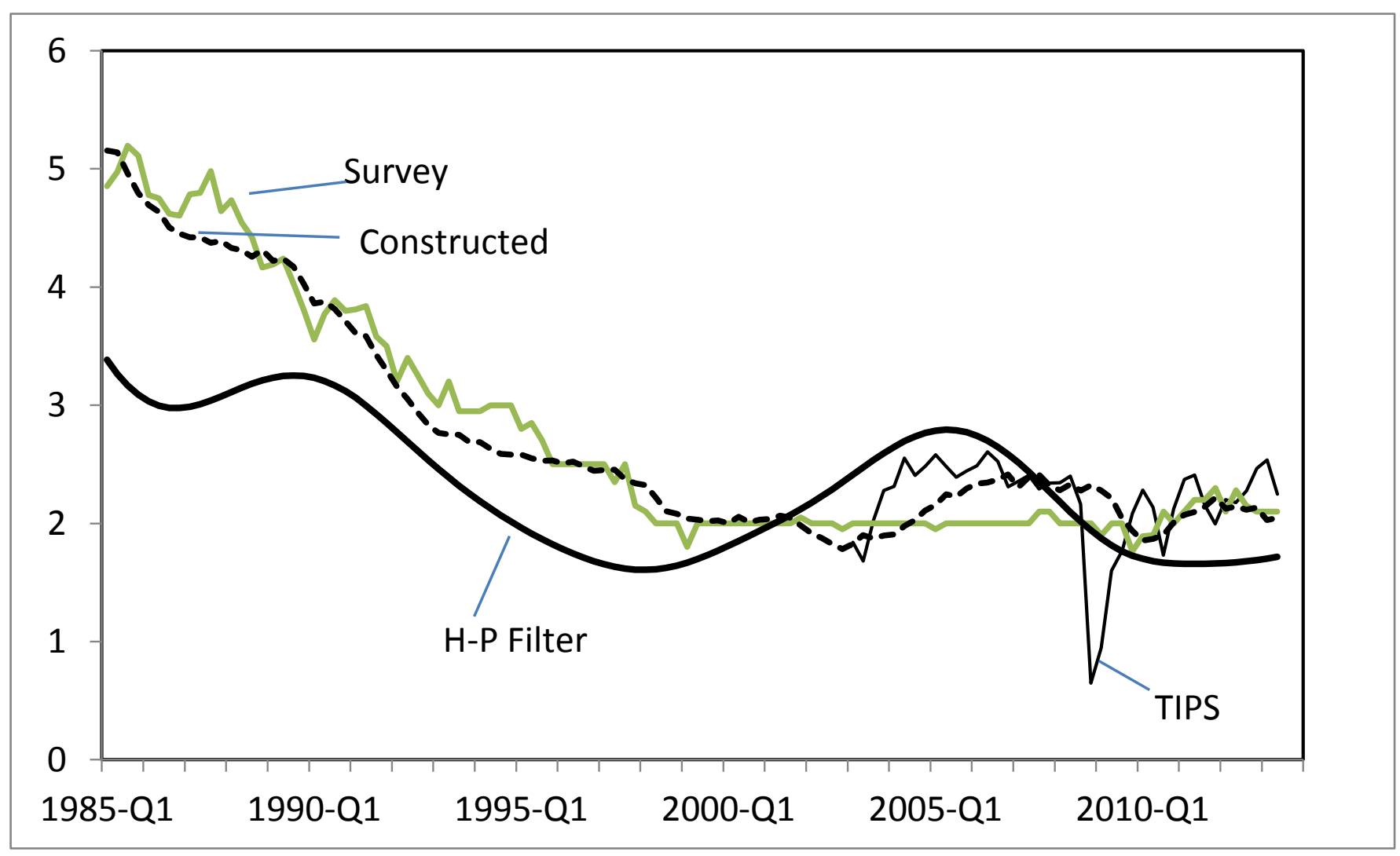

United Kingdom

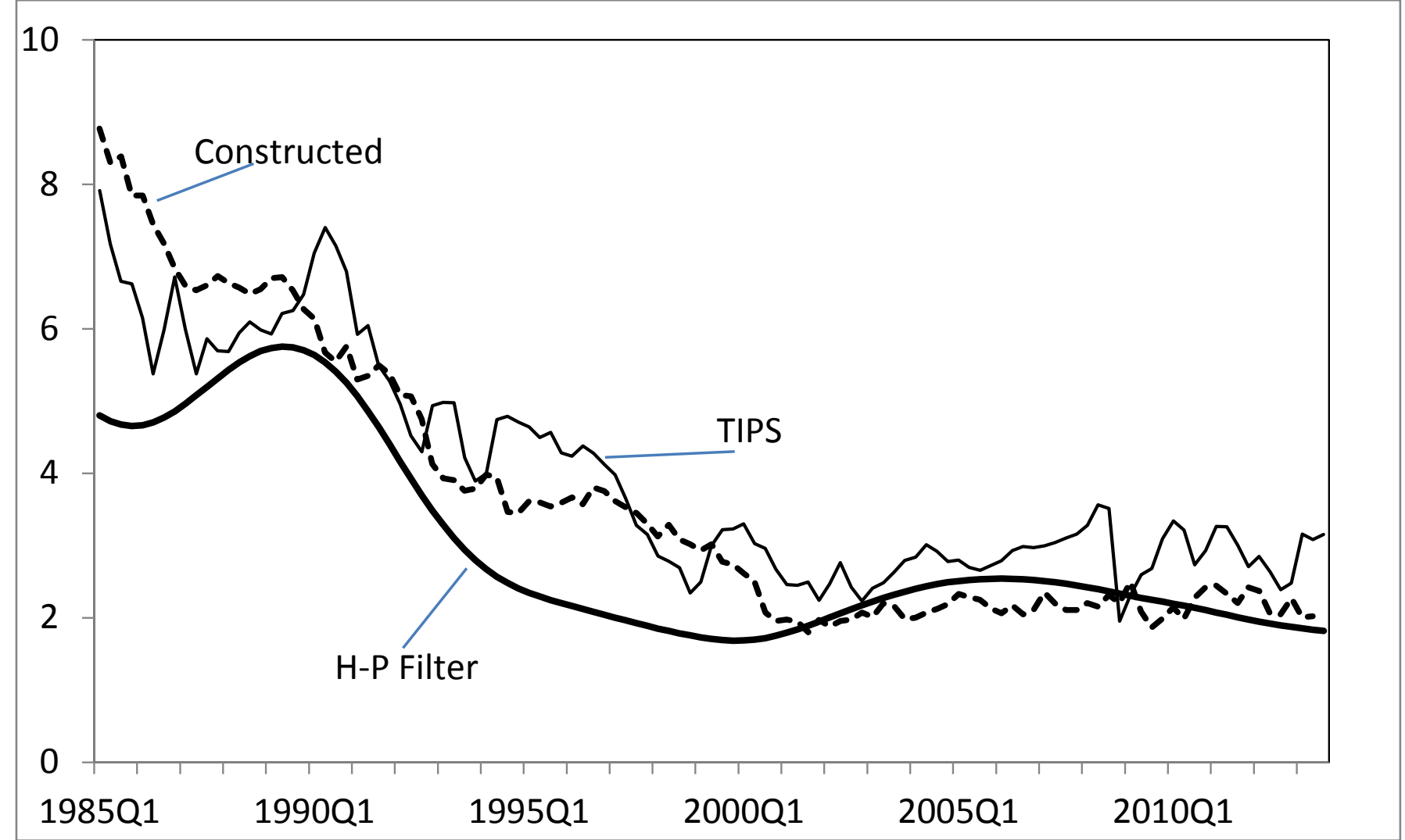

Source: author's calculations as explained in text. 
Figure 2. Short and Long Term World Interest Rates, 1970-2013

Short-term Rate

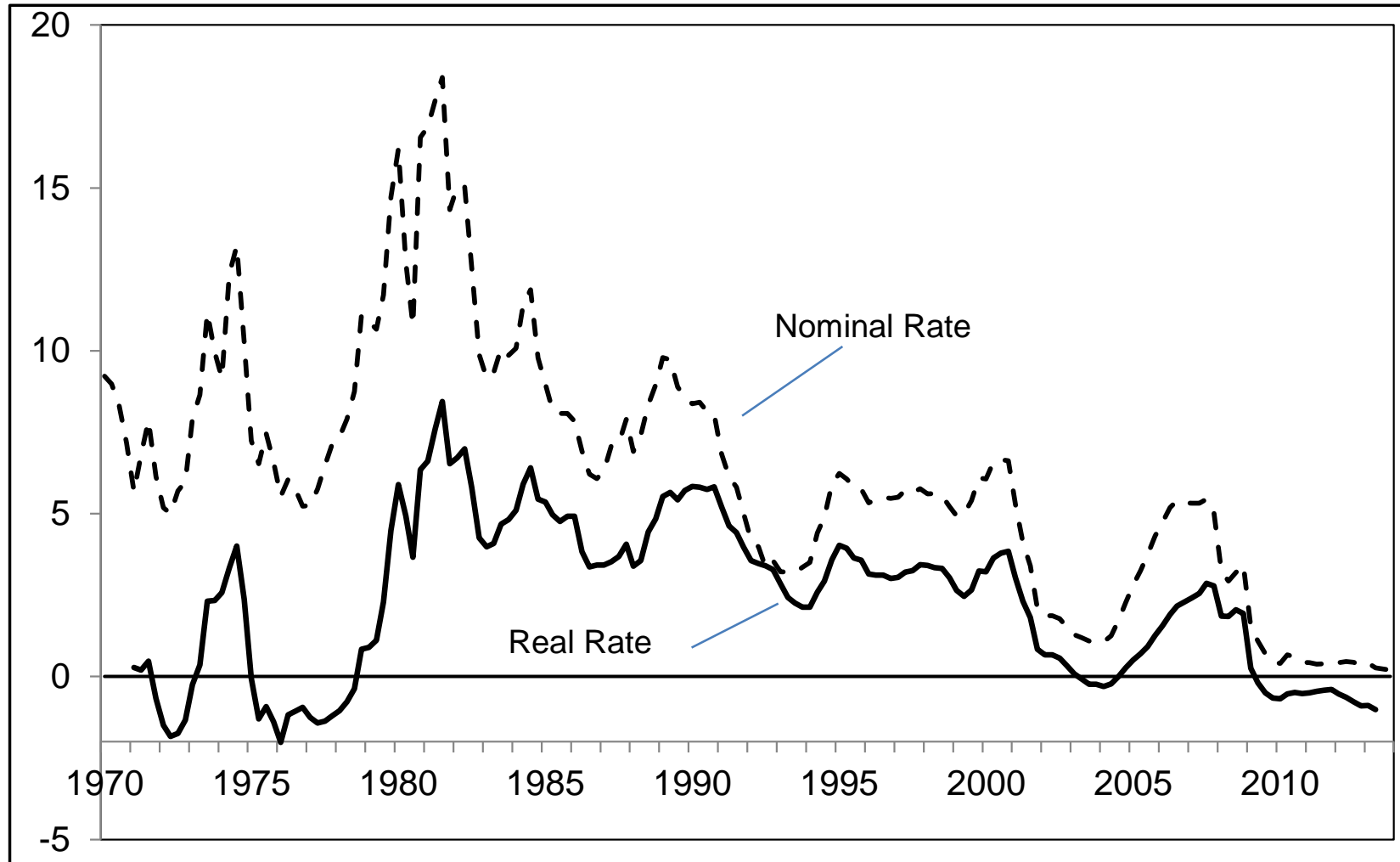

Long-term Rate

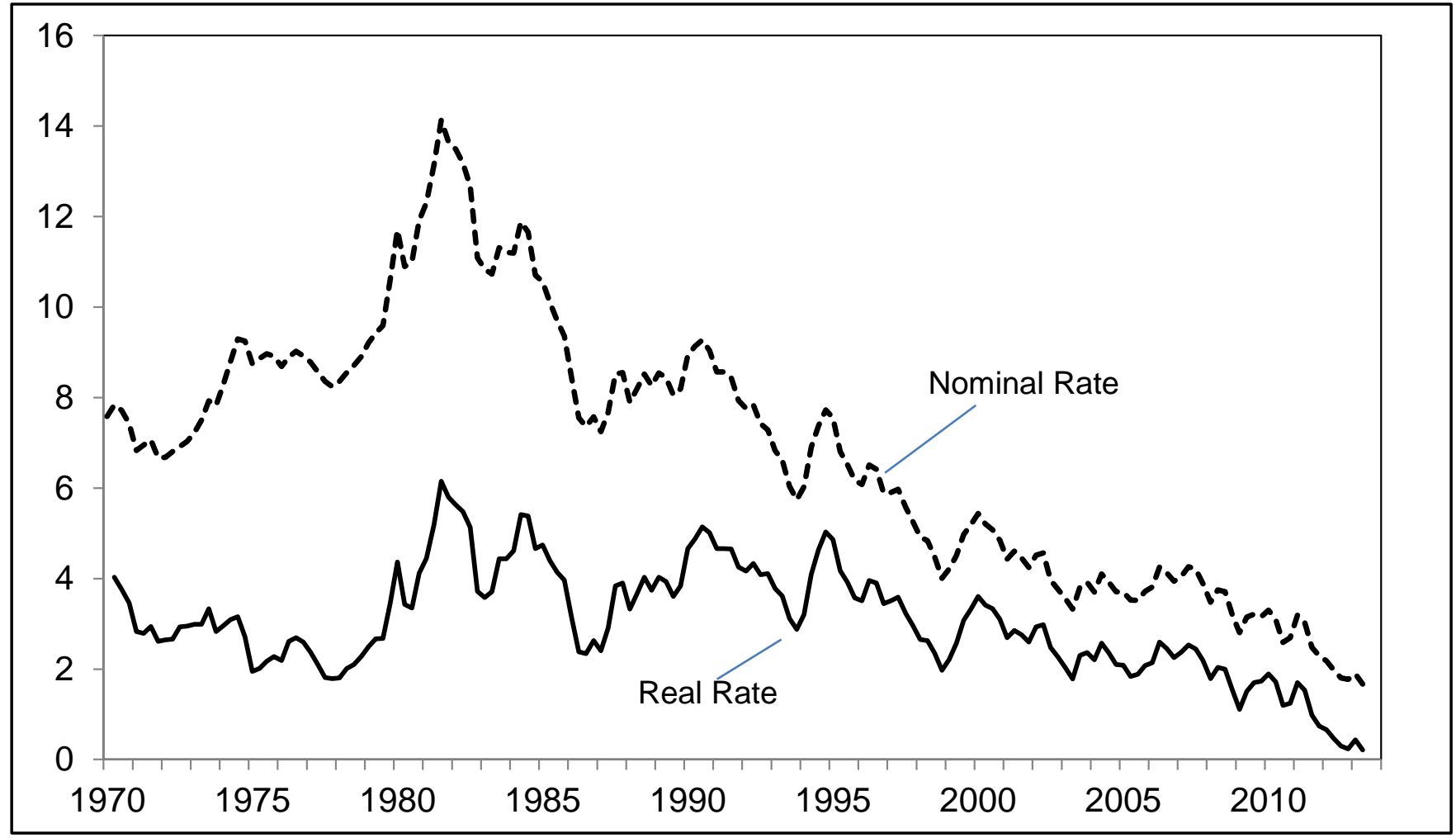

Source: Author's calculations as described in text. 
Figure 3. Standard Deviation of G-7 Interest Rates, 1970-2013

Standard Deviation, Short-term Rates

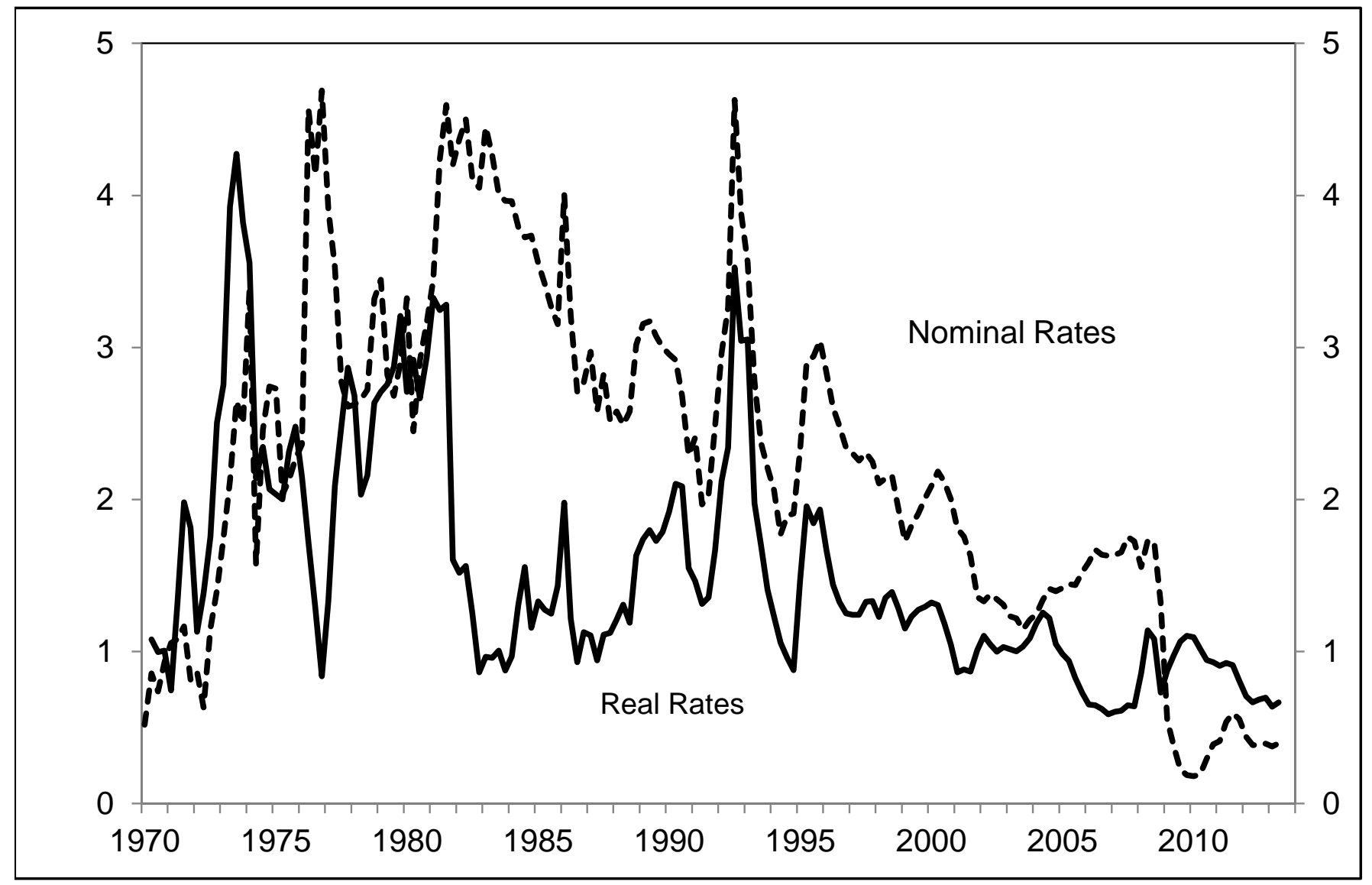

Standard Deviation, Long-term Rates

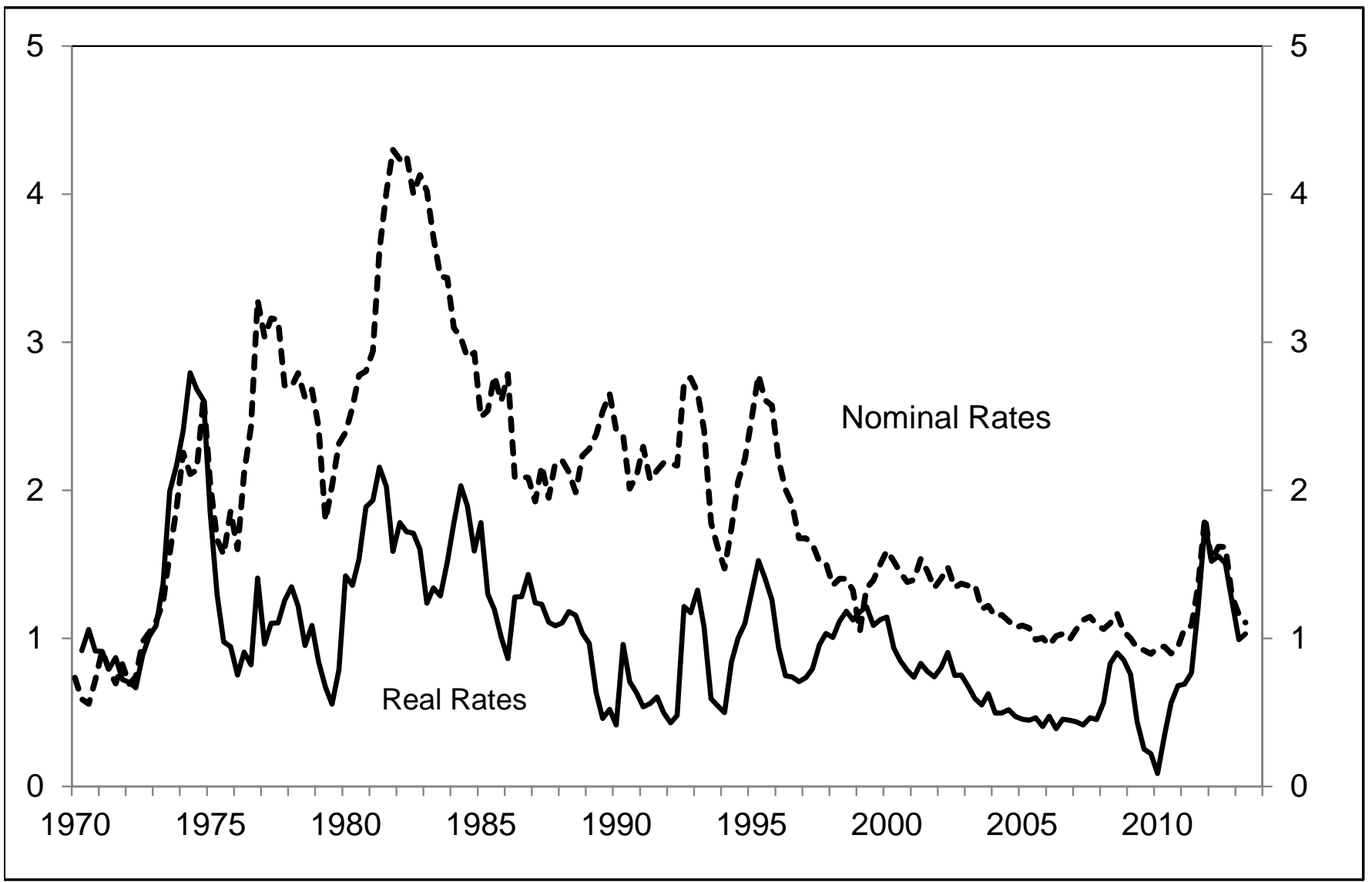

Source: author's calculations as described in the text. 
Table 1. Regressions for the Long-term Real Bond Rate, 1970-2012

\begin{tabular}{|c|c|c|c|c|c|c|}
\hline & $\begin{array}{c}\text { G-7 } \\
\text { Countries } \\
\text { Through } \\
2012 \\
\end{array}$ & $\begin{array}{c}\text { G-7 } \\
\text { Countries } \\
\text { Through } \\
2012 \\
\end{array}$ & $\begin{array}{c}\text { G-7 } \\
\text { Countries } \\
\text { Through } \\
2008\end{array}$ & $\begin{array}{c}\text { G-7 } \\
\text { Countries } \\
\text { Through } \\
2008\end{array}$ & $\begin{array}{c}19 \text { OECD } \\
\text { Countries } \\
\text { Through } \\
2012\end{array}$ & $\begin{array}{c}19 \text { OECD } \\
\text { Countries } \\
\text { Through } \\
2012\end{array}$ \\
\hline & (1) & (2) & (3) & $(4)$ & (5) & $(6)$ \\
\hline Own Rate $_{t-1}$ & & $\begin{array}{l}0.618 \\
(15.6)\end{array}$ & & $\begin{array}{l}0.599 \\
(14.4)\end{array}$ & & $\begin{array}{l}0.640 \\
(25.8)\end{array}$ \\
\hline Foreign Average Real & & & & & & \\
\hline Rate $^{1}$ & $\begin{array}{l}0.836 \\
(13.9)\end{array}$ & $\begin{array}{l}0.445 \\
(8.7)\end{array}$ & $\begin{array}{l}0.810 \\
(12.4)\end{array}$ & $\begin{array}{c}0.473 \\
(8.6)\end{array}$ & $\begin{array}{l}0.964 \\
(22.1)\end{array}$ & $\begin{array}{l}0.447 \\
(12.1)\end{array}$ \\
\hline Debt/GDP ${ }_{t-1}$ & $\begin{array}{c}0.010 \\
(3.9)\end{array}$ & $\begin{array}{l}0.007 \\
(3.8)\end{array}$ & $\begin{array}{l}0.009 \\
(3.3)\end{array}$ & $\begin{array}{l}0.007 \\
(3.4)\end{array}$ & $\begin{array}{c}0.010 \\
(4.8)\end{array}$ & $\begin{array}{c}0.004 \\
(2.9)\end{array}$ \\
\hline Current Account/GDP & $\begin{array}{l}0.007 \\
(.2)\end{array}$ & $\begin{array}{l}-0.050 \\
(-2.0)\end{array}$ & $\begin{array}{l}0.011 \\
(0.3)\end{array}$ & $\begin{array}{l}-0.040 \\
-(1.5)\end{array}$ & $\begin{array}{l}-0.033 \\
-(2.2)\end{array}$ & $\begin{array}{l}-0.044 \\
-(4.2)\end{array}$ \\
\hline $\begin{array}{l}\text { 3-Year Average of } \\
\text { GDP Growth }\end{array}$ & $\begin{array}{c}0.122 \\
(2.1)\end{array}$ & $\begin{array}{l}0.136 \\
(3.2)\end{array}$ & $\begin{array}{l}0.099 \\
(1.6)\end{array}$ & $\begin{array}{l}0.154 \\
(3.2)\end{array}$ & $\begin{array}{c}0.011 \\
(0.3)\end{array}$ & $\begin{array}{c}0.060 \\
(2.0)\end{array}$ \\
\hline Constant & $\begin{array}{c}-0.299 \\
(-0.9)\end{array}$ & $\begin{array}{l}-0.910 \\
-(3.7)\end{array}$ & $\begin{array}{c}-0.096 \\
(-0.3)\end{array}$ & $\begin{array}{l}-0.955 \\
-(3.4)\end{array}$ & $\begin{array}{c}-0.418 \\
(-2.0)\end{array}$ & $\begin{array}{c}-0.600 \\
(-4.0)\end{array}$ \\
\hline Observations & 303 & 303 & 282 & 282 & 723 & 722 \\
\hline R-squared & 0.40 & 0.67 & 0.36 & 0.64 & 0.43 & 0.71 \\
\hline Number of Countries & 7 & 7 & 7 & 7 & 19 & 19 \\
\hline
\end{tabular}

Source: authors's estimates as explained in the text.

1. For non-G-7 countries, the foreign rate is the G-7 average. 
Table 2. Regressions for the Short-term Real Interest Rate, 1970-2012

\begin{tabular}{lcccc}
\hline & $\begin{array}{c}\text { G-7 } \\
\text { Countries } \\
\text { Through } \\
2012\end{array}$ & $\begin{array}{c}\text { G-7 } \\
\text { Countries } \\
\text { Through } \\
2012\end{array}$ & $\begin{array}{c}\text { G-7 } \\
\text { Countries } \\
\text { Through } \\
2008\end{array}$ & $\begin{array}{c}\text { G-7 } \\
\text { Countries } \\
\text { Through } \\
2008\end{array}$ \\
\hline & $(1)$ & $(2)$ & $(3)$ & $(4)$ \\
\hline Own Rate $_{\text {t-1 }}$ & & 0.564 & & 0.571 \\
Foreign Average Real & & $(15.6)$ & & $(15.2)$ \\
Rate $^{1}$ & 0.945 & 0.519 & 0.927 & 0.513 \\
& $(19.3)$ & $(11.5)$ & $(17.3)$ & $(10.7)$ \\
Debt/GDP & 0.012 & 0.010 & 0.010 & 0.008 \\
& $(2.7)$ & $(2.9)$ & $(2.1)$ & $(2)$. \\
Current Account/GDP & -0.049 & -0.122 & -0.072 & -0.127 \\
& $-(.8)$ & $-(2.7)$ & $-(1.1)$ & $-(2.7)$ \\
3-Year Average of & & & & \\
GDP Growth & 0.080 & 0.266 & 0.006 & 0.243 \\
& $(.7)$ & $(3.2)$ & $(0.0)$ & $(2.6)$ \\
Constant & -0.789 & -1.323 & -0.466 & -1.148 \\
& -1.73 & $-(3.9)$ & $(-0.9)$ & $-(3.1)$ \\
Observations & & & & \\
R-squared & 297 & 294 & 276 & 273 \\
Number of Countries & 0.57 & 0.769 & 0.549 & 0.759 \\
Source: authors's estimates as explained in the text & 7 & 7 & 7 \\
\hline
\end{tabular}

1. For non-G-7 countries, the foreign rate is the G-7 average. 
Appendix 1: G-7 Interest Rates, Annual Averages,1970-2012

Year

\begin{tabular}{|c|c|c|c|c|c|c|c|c|}
\hline & Canada & France & Germany & Italy & Japan & UK & USA & G-7 \\
\hline 1970 & 7.32 & 8.93 & 9.41 & & 8.33 & 8.13 & 8.43 & \\
\hline 1971 & 4.49 & 6.29 & 7.15 & 5.76 & 6.57 & 6.25 & 6.63 & 6.63 \\
\hline 1972 & 5.01 & 5.51 & 5.61 & 5.17 & 5.13 & 7.56 & 5.47 & 5.47 \\
\hline 1973 & 7.18 & 9.13 & 12.14 & 6.93 & 8.33 & 11.83 & 9.42 & 9.42 \\
\hline 1974 & 10.37 & 13.02 & 9.90 & 14.57 & 14.51 & 13.49 & 11.26 & 11.26 \\
\hline 1975 & 7.88 & 7.92 & 4.96 & 10.63 & 9.88 & 10.64 & 6.95 & 6.95 \\
\hline 1976 & 9.12 & 8.69 & 4.25 & 15.68 & 7.17 & 11.60 & 5.64 & 5.64 \\
\hline 1977 & 7.36 & 9.22 & 4.37 & 14.04 & 6.30 & 7.97 & 6.16 & 6.16 \\
\hline 1978 & 8.56 & 8.16 & 3.70 & 11.56 & 5.07 & 9.24 & 8.78 & 8.78 \\
\hline 1979 & 11.75 & 9.48 & 6.69 & 11.77 & 6.03 & 13.68 & 12.01 & 12.01 \\
\hline 1980 & 12.90 & 12.21 & 9.54 & 16.79 & 10.88 & 16.62 & 14.06 & 14.06 \\
\hline 1981 & 18.06 & 15.26 & 12.11 & 19.23 & 7.58 & 13.91 & 16.83 & 16.83 \\
\hline 1982 & 14.13 & 14.62 & 8.88 & 19.91 & 7.03 & 12.29 & 13.13 & 13.13 \\
\hline 1983 & 9.30 & 12.47 & 5.78 & 18.31 & 6.69 & 10.13 & 9.61 & 9.61 \\
\hline 1984 & 11.03 & 11.70 & 5.99 & 17.27 & 6.46 & 9.94 & 10.78 & 10.78 \\
\hline 1985 & 9.43 & 9.94 & 5.45 & 15.25 & 6.63 & 12.24 & 8.33 & 8.33 \\
\hline 1986 & 9.03 & 7.71 & 4.64 & 13.39 & 5.17 & 10.94 & 6.76 & 6.76 \\
\hline 1987 & 8.26 & 8.27 & 4.03 & 11.33 & 4.23 & 9.70 & 7.12 & 7.12 \\
\hline 1988 & 9.44 & 7.94 & 4.33 & 10.82 & 4.53 & 10.33 & 7.90 & 7.90 \\
\hline 1989 & 11.97 & 9.40 & 7.12 & 12.62 & 5.38 & 13.89 & 9.25 & 9.25 \\
\hline 1990 & 12.79 & 10.32 & 8.49 & 12.23 & 7.72 & 14.77 & 8.25 & 8.25 \\
\hline 1991 & 8.88 & 9.62 & 9.25 & 12.21 & 7.38 & 11.52 & 5.95 & 5.95 \\
\hline 1992 & 6.50 & 10.34 & 9.52 & 14.01 & 4.46 & 9.62 & 3.77 & 3.77 \\
\hline 1993 & 4.98 & 8.59 & 7.30 & 10.20 & 2.98 & 5.94 & 3.24 & 3.24 \\
\hline 1994 & 5.47 & 5.85 & 5.36 & 8.51 & 2.23 & 5.50 & 4.68 & 4.68 \\
\hline 1995 & 7.04 & 6.58 & 4.53 & 10.46 & 1.23 & 6.68 & 5.97 & 5.97 \\
\hline 1996 & 4.48 & 3.94 & 3.31 & 8.82 & 0.59 & 6.03 & 5.44 & 5.44 \\
\hline 1997 & 3.58 & 3.46 & 3.33 & 6.88 & 0.60 & 6.83 & 5.66 & 5.66 \\
\hline 1998 & 5.06 & 3.56 & 3.54 & 4.99 & 0.72 & 7.34 & 5.50 & 5.50 \\
\hline 1999 & 4.95 & 2.96 & 2.96 & 2.96 & 0.25 & 5.45 & 5.36 & 5.36 \\
\hline 2000 & 5.68 & 4.39 & 4.39 & 4.39 & 0.25 & 6.11 & 6.48 & 6.48 \\
\hline 2001 & 4.04 & 4.26 & 4.26 & 4.26 & 0.12 & 4.97 & 3.73 & 3.73 \\
\hline 2002 & 2.63 & 3.32 & 3.32 & 3.32 & 0.06 & 3.99 & 1.76 & 1.76 \\
\hline 2003 & 3.00 & 2.33 & 2.33 & 2.33 & 0.04 & 3.67 & 1.17 & 1.17 \\
\hline 2004 & 2.36 & 2.11 & 2.11 & 2.11 & 0.03 & 4.57 & 1.58 & 1.58 \\
\hline 2005 & 2.83 & 2.18 & 2.18 & 2.18 & 0.03 & 4.70 & 3.53 & 3.53 \\
\hline 2006 & 4.14 & 3.08 & 3.08 & 3.08 & 0.25 & 4.80 & 5.17 & 5.17 \\
\hline 2007 & 4.60 & 4.28 & 4.28 & 4.28 & 0.66 & 5.96 & 5.28 & 5.28 \\
\hline 2008 & 3.45 & 4.63 & 4.63 & 4.63 & 0.74 & 5.49 & 3.20 & 3.20 \\
\hline 2009 & 0.82 & 1.23 & 1.23 & 1.23 & 0.35 & 1.20 & 0.94 & 0.94 \\
\hline 2010 & 0.82 & 0.81 & 0.81 & 0.81 & 0.16 & 0.69 & 0.53 & 0.53 \\
\hline 2011 & 1.21 & 1.39 & 1.39 & 1.39 & 0.12 & 0.89 & 0.42 & 0.42 \\
\hline 2012 & 1.31 & 0.57 & 0.57 & 0.57 & 0.12 & 0.84 & 0.42 & 0.42 \\
\hline
\end{tabular}

Short-term Real Interest Rate

\begin{tabular}{|c|c|c|c|c|c|c|c|}
\hline \multicolumn{8}{|c|}{ Short-term Real Interest Rate } \\
\hline Canada & France & Germany & Italy & Japan & UK & USA & G-7 \\
\hline 1.99 & 2.71 & 3.08 & & 1.40 & 1.15 & 3.33 & \\
\hline-1.66 & -0.55 & 1.03 & -2.12 & -1.32 & -2.00 & 1.21 & 0.07 \\
\hline-2.39 & -2.21 & -0.29 & -4.71 & -3.90 & -2.45 & -0.40 & -1.60 \\
\hline-1.52 & 0.13 & 6.08 & -5.23 & -1.96 & -0.52 & 2.72 & 1.19 \\
\hline 0.81 & 2.86 & 4.32 & -0.22 & 3.60 & -0.85 & 3.94 & 3.07 \\
\hline-1.44 & -2.16 & 0.14 & -4.62 & 0.36 & -4.28 & -0.28 & -0.92 \\
\hline 0.00 & -1.50 & -0.08 & -0.78 & -0.78 & -3.42 & -1.57 & -1.30 \\
\hline-1.35 & -0.97 & 0.27 & -2.32 & -0.17 & -6.10 & -1.21 & -1.31 \\
\hline-0.25 & -1.99 & -0.34 & -4.51 & -0.06 & -4.40 & 1.04 & -0.34 \\
\hline 2.56 & -0.94 & 2.46 & -4.46 & 1.88 & 0.25 & 3.95 & 2.20 \\
\hline 3.74 & 1.47 & 5.23 & -0.05 & 7.39 & 4.15 & 6.11 & 5.21 \\
\hline 9.13 & 4.49 & 7.94 & 2.70 & 4.97 & 3.62 & 9.42 & 7.30 \\
\hline 6.57 & 4.62 & 5.24 & 4.54 & 5.09 & 4.09 & 7.00 & 5.94 \\
\hline 3.29 & 3.79 & 2.74 & 4.87 & 5.20 & 3.70 & 4.74 & 4.39 \\
\hline 5.97 & 4.42 & 3.38 & 5.84 & 5.23 & 4.55 & 6.74 & 5.72 \\
\hline 5.07 & 4.08 & 3.12 & 5.70 & 5.54 & 7.19 & 4.94 & 5.00 \\
\hline 4.93 & 3.07 & 2.42 & 5.27 & 4.13 & 5.91 & 3.66 & 3.89 \\
\hline 4.24 & 4.44 & 1.73 & 4.13 & 3.10 & 4.34 & 3.97 & 3.68 \\
\hline 5.46 & 4.67 & 1.69 & 4.02 & 3.14 & 4.51 & 4.60 & 4.06 \\
\hline 8.17 & 6.47 & 3.92 & 5.89 & 3.71 & 7.71 & 5.82 & 5.58 \\
\hline 9.43 & 7.69 & 4.79 & 5.76 & 5.91 & 8.83 & 4.91 & 5.80 \\
\hline 6.18 & 7.32 & 5.25 & 6.20 & 5.74 & 6.47 & 2.90 & 4.56 \\
\hline 4.35 & 8.35 & 5.61 & 8.52 & 3.26 & 5.59 & 1.09 & 3.43 \\
\hline 3.20 & 6.92 & 3.95 & 5.39 & 2.27 & 2.82 & 0.87 & 2.42 \\
\hline 3.88 & 4.46 & 2.80 & 4.16 & 1.96 & 2.90 & 2.53 & 2.81 \\
\hline 5.56 & 5.35 & 2.76 & 6.39 & 1.28 & 4.31 & 4.00 & 3.80 \\
\hline 3.13 & 2.86 & 2.23 & 5.24 & 0.83 & 3.84 & 3.65 & 3.10 \\
\hline 2.26 & 2.45 & 2.72 & 3.79 & 1.03 & 4.79 & 3.97 & 3.24 \\
\hline 3.54 & 2.50 & 3.19 & 2.29 & 1.41 & 5.44 & 3.82 & 3.28 \\
\hline 3.08 & 1.75 & 2.67 & 0.48 & 1.21 & 3.68 & 3.58 & 2.75 \\
\hline 3.50 & 2.89 & 3.96 & 1.88 & 1.45 & 4.32 & 4.52 & 3.62 \\
\hline 1.70 & 2.51 & 3.59 & 1.67 & 1.49 & 3.05 & 1.64 & 2.00 \\
\hline 0.08 & 1.41 & 2.47 & 0.70 & 1.52 & 1.87 & -0.49 & 0.56 \\
\hline 0.21 & 0.34 & 1.41 & -0.19 & 1.49 & 1.34 & -1.30 & -0.12 \\
\hline-0.56 & 0.05 & 1.18 & -0.28 & 1.41 & 2.07 & -1.10 & -0.06 \\
\hline-0.10 & 0.09 & 1.27 & -0.06 & 1.34 & 2.12 & 0.73 & 0.85 \\
\hline 1.32 & 0.97 & 2.14 & 0.93 & 1.51 & 2.21 & 2.43 & 1.98 \\
\hline 2.05 & 2.25 & 3.30 & 2.21 & 1.93 & 3.39 & 2.82 & 2.66 \\
\hline 1.27 & 2.81 & 3.63 & 2.73 & 2.08 & 3.04 & 1.12 & 1.92 \\
\hline-1.09 & -0.30 & 0.24 & -0.40 & 1.76 & -1.04 & -0.84 & -0.27 \\
\hline-1.04 & -0.54 & -0.21 & -0.63 & 1.55 & -1.43 & -1.13 & -0.55 \\
\hline-0.58 & 0.15 & 0.27 & 0.05 & 1.29 & -1.11 & -1.22 & -0.44 \\
\hline-0.37 & -0.53 & -0.68 & -0.67 & 0.85 & -1.05 & -1.24 & -0.71 \\
\hline
\end{tabular}


Continued

Year

\begin{tabular}{|c|c|c|c|c|c|c|c|c|}
\hline & Canada & France & Germany & Italy & Japan & UK & USA & G-7 \\
\hline 1970 & 7.97 & 8.55 & 8.32 & 7.73 & 7.05 & 8.63 & 7.35 & 7.64 \\
\hline 1971 & 6.95 & 8.42 & 7.99 & 7.00 & 7.05 & 7.87 & 6.16 & 6.88 \\
\hline 1972 & 7.23 & 8.01 & 7.87 & 6.59 & 6.88 & 8.38 & 6.21 & 6.86 \\
\hline 1973 & 7.53 & 9.00 & 9.31 & 6.92 & 7.14 & 10.56 & 6.84 & 7.62 \\
\hline 1974 & 8.87 & 11.00 & 10.44 & 9.61 & 8.19 & 14.21 & 7.56 & 8.91 \\
\hline 1975 & 8.99 & 10.31 & 8.68 & 10.04 & 8.46 & 13.18 & 7.99 & 8.87 \\
\hline 1976 & 9.23 & 10.51 & 8.03 & 12.66 & 8.59 & 13.61 & 7.61 & 8.88 \\
\hline 1977 & 8.69 & 10.99 & 6.53 & 14.71 & 7.47 & 12.03 & 7.42 & 8.49 \\
\hline 1978 & 9.24 & 10.61 & 6.13 & 13.05 & 6.37 & 12.07 & 8.41 & 8.63 \\
\hline 1979 & 10.18 & 10.85 & 7.57 & 13.02 & 8.33 & 12.95 & 9.44 & 9.71 \\
\hline 1980 & 12.34 & 13.78 & 8.43 & 15.25 & 8.87 & 13.91 & 11.46 & 11.38 \\
\hline 1981 & 14.99 & 16.29 & 10.13 & 19.36 & 8.38 & 14.88 & 13.91 & 13.31 \\
\hline 1982 & 14.44 & 16.00 & 8.91 & 20.21 & 8.29 & 13.09 & 13.00 & 12.61 \\
\hline 1983 & 11.40 & 14.37 & 8.08 & 18.30 & 7.81 & 11.27 & 11.11 & 11.02 \\
\hline 1984 & 12.71 & 13.40 & 7.96 & 15.60 & 7.32 & 11.13 & 12.44 & 11.36 \\
\hline 1985 & 10.91 & 11.87 & 7.04 & 13.71 & 6.49 & 10.97 & 10.62 & 9.93 \\
\hline 1986 & 9.15 & 9.12 & 6.16 & 11.47 & 5.15 & 10.14 & 7.68 & 7.73 \\
\hline 1987 & 9.47 & 9.48 & 6.25 & 10.64 & 5.02 & 9.57 & 8.38 & 8.00 \\
\hline 1988 & 9.83 & 9.08 & 6.49 & 10.90 & 4.79 & 9.68 & 8.85 & 8.22 \\
\hline 1989 & 9.78 & 8.80 & 7.03 & 12.79 & 5.13 & 10.19 & 8.50 & 8.31 \\
\hline 1990 & 10.73 & 9.93 & 8.71 & 13.54 & 6.96 & 11.80 & 8.55 & 9.10 \\
\hline 1991 & 9.46 & 9.04 & 8.46 & 13.28 & 6.34 & 10.11 & 7.86 & 8.38 \\
\hline 1992 & 8.06 & 8.59 & 7.85 & 13.27 & 5.33 & 9.06 & 7.01 & 7.58 \\
\hline 1993 & 7.24 & 6.78 & 6.52 & 11.19 & 4.32 & 7.48 & 5.87 & 6.31 \\
\hline 1994 & 8.36 & 7.22 & 6.88 & 10.52 & 4.36 & 8.12 & 7.08 & 7.01 \\
\hline 1995 & 8.16 & 7.54 & 6.86 & 12.21 & 3.44 & 8.20 & 6.58 & 6.76 \\
\hline 1996 & 7.24 & 6.31 & 6.23 & 9.40 & 3.10 & 7.81 & 6.44 & 6.22 \\
\hline 1997 & 6.14 & 5.58 & 5.66 & 6.86 & 2.37 & 7.05 & 6.35 & 5.68 \\
\hline 1998 & 5.28 & 4.64 & 4.58 & 4.88 & 1.54 & 5.55 & 5.26 & 4.56 \\
\hline 1999 & 5.54 & 4.61 & 4.49 & 4.73 & 1.75 & 5.09 & 5.64 & 4.72 \\
\hline 2000 & 5.93 & 5.39 & 5.26 & 5.58 & 1.74 & 5.33 & 6.03 & 5.14 \\
\hline 2001 & 5.48 & 4.94 & 4.80 & 5.19 & 1.32 & 4.93 & 5.02 & 4.43 \\
\hline 2002 & 5.30 & 4.86 & 4.78 & 5.03 & 1.26 & 4.90 & 4.61 & 4.20 \\
\hline 2003 & 4.80 & 4.13 & 4.07 & 4.30 & 1.00 & 4.53 & 4.02 & 3.65 \\
\hline 2004 & 4.58 & 4.10 & 4.04 & 4.26 & 1.49 & 4.88 & 4.27 & 3.86 \\
\hline 2005 & 4.07 & 3.41 & 3.35 & 3.56 & 1.35 & 4.41 & 4.29 & 3.61 \\
\hline 2006 & 4.21 & 3.80 & 3.76 & 4.05 & 1.74 & 4.50 & 4.79 & 4.03 \\
\hline 2007 & 4.27 & 4.30 & 4.22 & 4.49 & 1.67 & 5.01 & 4.63 & 4.10 \\
\hline 2008 & 3.60 & 4.23 & 3.98 & 4.68 & 1.47 & 4.59 & 3.67 & 3.53 \\
\hline 2009 & 3.23 & 3.65 & 3.22 & 4.31 & 1.33 & 3.65 & 3.26 & 3.08 \\
\hline 2010 & 3.24 & 3.12 & 2.74 & 4.04 & 1.15 & 3.61 & 3.21 & 2.92 \\
\hline 2011 & 2.79 & 3.32 & 2.61 & 5.42 & 1.10 & 3.12 & 2.79 & 2.75 \\
\hline 2012 & 1.87 & 2.54 & 1.50 & 5.49 & 0.84 & 1.91 & 1.80 & 1.93 \\
\hline
\end{tabular}

Long-term Real Interest Rate

\begin{tabular}{|c|c|c|c|c|c|c|c|}
\hline \multicolumn{8}{|c|}{ Long-term Real Interest Rate } \\
\hline Canada & France & Germany & Italy & Japan & UK & USA & G-7 \\
\hline 4.36 & 4.15 & 4.17 & 3.35 & 1.78 & 4.49 & 4.13 & 3.75 \\
\hline 3.52 & 3.80 & 3.50 & 2.04 & 1.79 & 2.94 & 2.83 & 2.79 \\
\hline 3.33 & 3.22 & 3.69 & 1.83 & 2.06 & 3.28 & 2.79 & 2.80 \\
\hline 2.67 & 3.95 & 4.97 & 1.24 & 1.02 & 5.02 & 3.10 & 3.04 \\
\hline 2.18 & 4.87 & 5.51 & 1.85 & -0.39 & 7.28 & 2.79 & 2.98 \\
\hline 2.08 & 2.89 & 3.60 & 0.91 & 0.48 & 2.90 & 2.23 & 2.10 \\
\hline 2.45 & 3.04 & 3.66 & 3.43 & 1.70 & 2.99 & 2.26 & 2.52 \\
\hline 2.20 & 3.37 & 2.23 & 3.37 & 0.34 & 2.14 & 2.08 & 2.02 \\
\hline 2.78 & 2.96 & 1.74 & 2.12 & -0.22 & 1.83 & 2.68 & 2.05 \\
\hline 3.01 & 2.71 & 2.96 & 1.69 & 2.15 & 2.35 & 3.25 & 2.82 \\
\hline 4.29 & 4.97 & 3.63 & 1.66 & 2.62 & 1.20 & 4.74 & 3.81 \\
\hline 6.02 & 6.82 & 5.63 & 4.98 & 2.20 & 2.62 & 6.61 & 5.40 \\
\hline 5.76 & 6.01 & 4.44 & 5.19 & 2.75 & 2.14 & 6.04 & 4.99 \\
\hline 3.43 & 4.77 & 4.06 & 3.52 & 3.15 & 0.98 & 4.82 & 4.04 \\
\hline 5.80 & 4.35 & 4.46 & 2.14 & 3.69 & 1.58 & 6.56 & 5.02 \\
\hline 4.87 & 4.01 & 3.99 & 1.59 & 3.45 & 2.44 & 5.34 & 4.31 \\
\hline 3.61 & 1.80 & 2.97 & 0.09 & 2.53 & 2.62 & 2.97 & 2.62 \\
\hline 3.88 & 2.90 & 3.32 & 0.56 & 2.96 & 2.77 & 3.81 & 3.26 \\
\hline 4.23 & 3.00 & 3.83 & 1.11 & 3.25 & 2.93 & 4.36 & 3.69 \\
\hline 4.38 & 3.02 & 4.13 & 3.41 & 3.35 & 3.41 & 4.16 & 3.85 \\
\hline 5.92 & 4.66 & 5.80 & 4.52 & 5.08 & 5.70 & 4.56 & 4.92 \\
\hline 5.34 & 4.47 & 5.57 & 4.92 & 4.56 & 4.49 & 4.23 & 4.56 \\
\hline 4.76 & 4.72 & 4.47 & 5.96 & 3.64 & 4.11 & 3.90 & 4.17 \\
\hline 4.40 & 3.62 & 3.29 & 5.25 & 2.95 & 3.50 & 3.05 & 3.35 \\
\hline 5.69 & 4.55 & 3.96 & 5.12 & 3.18 & 4.26 & 4.34 & 4.24 \\
\hline 5.38 & 5.18 & 4.10 & 6.92 & 2.56 & 4.46 & 3.93 & 4.13 \\
\hline 4.61 & 4.19 & 3.78 & 4.18 & 2.38 & 3.97 & 3.85 & 3.70 \\
\hline 3.82 & 3.71 & 3.52 & 2.42 & 1.55 & 3.46 & 3.85 & 3.32 \\
\hline 3.52 & 2.87 & 2.51 & 0.88 & 0.62 & 2.35 & 3.02 & 2.40 \\
\hline 4.00 & 3.21 & 2.55 & 1.02 & 1.26 & 2.17 & 3.54 & 2.80 \\
\hline 3.68 & 3.98 & 3.78 & 2.32 & 1.63 & 2.98 & 3.93 & 3.36 \\
\hline 3.35 & 3.36 & 3.34 & 2.13 & 1.37 & 2.95 & 2.92 & 2.73 \\
\hline 3.96 & 3.23 & 3.31 & 2.01 & 1.64 & 2.87 & 2.71 & 2.66 \\
\hline 2.62 & 2.51 & 2.88 & 1.26 & 1.56 & 2.39 & 2.10 & 2.12 \\
\hline 2.38 & 2.51 & 2.99 & 1.45 & 2.16 & 2.73 & 2.22 & 2.31 \\
\hline 1.79 & 1.80 & 2.49 & 1.06 & 1.95 & 2.12 & 2.01 & 1.97 \\
\hline 1.79 & 2.09 & 3.00 & 1.76 & 2.44 & 2.36 & 2.37 & 2.36 \\
\hline 1.93 & 2.37 & 3.24 & 2.27 & 2.32 & 2.76 & 2.22 & 2.39 \\
\hline 0.64 & 2.22 & 2.96 & 2.21 & 2.39 & 2.32 & 1.33 & 1.84 \\
\hline 1.48 & 1.76 & 2.21 & 2.00 & 1.93 & 1.51 & 1.12 & 1.51 \\
\hline 1.08 & 1.48 & 1.57 & 2.06 & 2.13 & 1.38 & 1.28 & 1.51 \\
\hline 0.38 & 1.56 & 1.52 & 3.54 & 2.18 & 0.75 & 0.64 & 1.24 \\
\hline-0.50 & 0.83 & 0.38 & 3.54 & 1.72 & -0.27 & -0.32 & 0.42 \\
\hline
\end{tabular}




\section{RECENT WORKING PAPERS FROM THE CENTER FOR RETIREMENT RESEARCH AT BOSTON COLLEGE}

The Tradeoff Between Health and Wealth in Retirement Decisions

Kristine M. Brown, May 2014

The Effect of Increasing Earnings Dispersion on Social Security Payroll Tax Receipts Richard Kopcke, Zhenyu Li, and Anthony Webb, May 2014

What Impact Does Social Security Have on the Use of Public Assistance Programs Among the Elderly?

Norma B. Coe and April Yanyuan Wu, May 2014

Differential Mortality and Retirement Benefits in the Health and Retirement Study Barry P. Bosworth and Kathleen Burke, April 2014

Adding Employer Contributions to Health Insurance To Social Security's Earnings and Tax Base

Karen E. Smith and Eric Toder, April 2014

Lower-Income Individuals Without Pensions: Who Misses Out and Why?

April Yanyuan Wu and Matthew S. Rutledge, March 2014

How Do Subjective Longevity Expectations Influence Retirement Plans?

Mashfiqur R. Khan, Matthew S. Rutledge, and April Yanyuan Wu, January 2014

Impact of the Great Recession on Retirement Trends in Industrialized Countries Gary Burtless and Barry P. Bosworth, December 2013

Does Household Debt Influence the Labor Supply and Benefit Claiming Decisions of Older Americans?

Barbara A. Butrica and Nadia S. Karamcheva, December 2013

Point of No Return: How Do Financial Resources Affect the Timing of Retirement After a Job Separation?

Matthew S. Rutledge, December 2013

All working papers are available on the Center for Retirement Research website (http://crr.bc.edu) and can be requested by e-mail (crr@bc.edu) or phone (617-552-1762). 